Hydrol. Earth Syst. Sci. Discuss., 8, 1765-1797, 2011

www.hydrol-earth-syst-sci-discuss.net/8/1765/2011/

doi:10.5194/hessd-8-1765-2011

(C) Author(s) 2011. CC Attribution 3.0 License.
Hydrology and

Earth System

Sciences

Discussions

\title{
Hydrologic analysis for river Nyando using SWAT
}

A. O. Opere ${ }^{1}$ and B. N. Okello ${ }^{2}$

${ }^{1}$ University of Nairobi, Department of Meteorology, P.O. Box 30197, Nairobi, Kenya

${ }^{2}$ University of Nairobi, Department of Civil Engineering, P.O. Box 30197, Nairobi, Kenya

Received: 13 January 2011 - Accepted: 14 January 2011 - Published: 9 February 2011

Correspondence to: A. O. Opere (aopere@uonbi.ac.ke)

Published by Copernicus Publications on behalf of the European Geosciences Union.

\section{HESSD}

$8,1765-1797,2011$

Hydrologic analysis for river Nyando using SWAT

A. O. Opere and B. N. Okello

Title Page

Abstract

Introduction

Conclusions

References

Tables

Figures

14

4

Back

Full Screen / Esc

Printer-friendly Version

Interactive Discussion 


\section{Abstract}

The Nyando River is one of the major Rivers in the Lake Victoria Basin. It drains parts of Nandi, Kericho and Nyando districts. It has a catchment area of about $3600 \mathrm{~km}^{-2}$ of Western Kenya and an average discharge of approximately $15 \mathrm{~m}^{3} \mathrm{~s}^{-1}$, and has within 5 it some of the most severe problems of environmental degradation and deepening poverty found anywhere in Kenya. The Nyando River drains into the Winam Gulf of Lake Victoria and is a major contributor of sediment.

The primary role of GIS in hydrological modeling is to integrate the ever increasing volumes of diverse spatial and non spatial data. This can be the model input or output.

10 Recent advance in GIS (hardware and software) technology offer unprecedented capabilities for storing and manipulating large quantities of detailed, spatially-distributed watershed data (ASCE, 1999). SWAT, which is an interface of Arc View GIS, uses Arc View to prepare input data and display the model output as spatial maps, charts or time series data. This makes it easy to study and display the information for assimilation by 15 SWAT.

SWAT is a continuous time model that operates on a daily/sub-daily time step. It is physically based and can operate on large basins for long periods of time (Arnold et al., 1998). The basic model inputs are rainfall, maximum and minimum temperature, radiation, wind speed, relative humidity, land cover, soil and elevation (DEM). The watershed is subdivided into sub-basins that are spatially related to one another. Routing in stream channel is divided in to Water, Sediment, nutrients and organic chemical routing (Neitsch et al., 2002a).

Stream flow data was available for two Stations 1GD03 and 1GD07. The stations had data ranging from 1950 to 1997, though they had missing gaps.

Rainfall data were available for twelve rainfall recording stations in and around the basin. The collected data ranges between 1960 and 2000 though there were quite a number of missing data. The other weather data used were temperature data (maximum and minimum) for Kericho and Kisumu Meteorological stations.
HESSD

8, 1765-1797, 2011

\section{Hydrologic analysis for river Nyando using SWAT}

A. O. Opere and B. N. Okello

Title Page

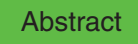

Introduction

Conclusions

References

Tables

Figures

14

4

Back

Close

Full Screen / Esc

Printer-friendly Version

Interactive Discussion 
During the study the available water capacity (SOL_AWC) was varied within the range of $\pm 0.05 \mathrm{~mm}$ of water $/ \mathrm{mm}$ of soil. The result showed that SOL_AWC affects the stream flow. SOL_AWC affects both the surface flow and base flow. An increase in SOL_AWC results in decrease on the stream flow because of increase in the ability of the soil to 5 hold more water. An increase in the initial curve number (CN2) increases the stream flow, but the effect is more pronounced on the effects on surface run off. The slightly increase in total stream flow could be as a result of ration of surface run off to base flow. The amount of stream flow contributed by the base flow was more than $50 \%$ of the total stream flow as show by base flow separation. The goodness of fit between observed 10 and simulated stream flow was assessed for the aforementioned (1GD03) station, the $R^{2}$ was found to be 0.24 while the NSE was 0.46 respectively. The low value of $R^{2}$ and NSE could be attributed to lots of data gaps in the station and also the effects of combined tributaries. The station is located about $10 \mathrm{~km}$ upstream of Ahero Bridge just before the flood plain. The model over estimated the low flows at this station while the 15 high flows were well estimated.

The performance of the model varied depending on the available input data. The coefficient of determination $R^{2}$ varies for observed and simulated stream flow at River gauging Station. The relationship between land use/cover change and stream flow is very significant in Nyando basin. The observation made is that with decreased Forest Cover up to $0 \%$ there is increased stream flow mean and peak and increased forests cover i.e. $100 \%$ results in decreased mean and peak stream flow.

\section{Introduction}

The Nyando River is one of the major rivers in the Lake Victoria Basin. It drains parts of Nandi, Kericho and Nyando districts. It has a catchment area of about $3600 \mathrm{~km}^{-2}$ of Western Kenya and an average discharge of approximately $15 \mathrm{~m}^{3} \mathrm{~s}^{-1}$, and has within it some of the most severe problems of environmental degradation and deepening

\section{HESSD}

$8,1765-1797,2011$

\section{Hydrologic analysis for river Nyando using SWAT}

A. O. Opere and B. N. Okello

Title Page

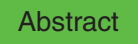

Introduction

Conclusions

Tables

References

Figures

14

$\rightarrow$

4

Back

Close

Full Screen / Esc

Printer-friendly Version

Interactive Discussion 
poverty found anywhere in Kenya. The Nyando River drains into the Winam Gulf of Lake Victoria and is a major contributor of sediment.

It has a unique physiographic characteristics, climate and elevation variation. Geologically the basin consists of extrusive igneous (volcanic) rocks mainly phonolites and 5 metamorphic rocks.

This is a basin area of variable welfare and environmental quality, with relatively tight cause and effect relation between upstream land and water uses and downstream variation in water quality and water quantity. The historical pattern shows consistent deforestation and degradation over the last hundred years, punctuated by severe wors10 ening of those problems during the heavy rains that accompany El Nino events. Floods in the Kano plain are becoming more severe and frequent as the river has gradually lost its ability to buffer environmental variability.

The basin drains parts of Nandi, Kericho, and Nyando districts, traversing from high to low potential areas. It is made up of six sub catchments namely Mbogo,Tugunon, 15 Masaita, Namuting, Ainapsiwa and Nyando. The basin has a humid climate with moderate temperatures and bimodal rainfall with a mean annual rainfall of $1200 \mathrm{~mm}$

\subsection{Effects of land use/cover change on stream flow}

The effects of land use/change on stream flows are manifested at different spatial and temporal scales. The possible changes in land use/cover include deforestation (afforestation) intensification of agriculture, drainage of wetlands and urbanization.

Deforestation which has converse effects to afforestation affects significantly the characteristics of the stream flow (Calder, 1992). Though considered a myth or folklore (McCulloch and Robbinson, 1993; Calder, 1998) forests are thought to make rain regulate low flows, reduce floods, ameliorate soil erosion and sterilize water. Intensification

\section{HESSD}

$8,1765-1797,2011$

\section{Hydrologic analysis for river Nyando using SWAT}

A. O. Opere and B. N. Okello

Title Page

Abstract Introduction

Conclusions

Tables

References

Figures

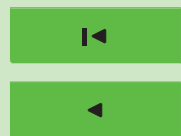

$\rightarrow$ I

Back

Close

Full Screen / Esc

Printer-friendly Version

Interactive Discussion 
Wetlands do not or marginally affect the basin's seasonal water balance (Calder, 1998). However due to the presence of free water surface and lack of water stress, the wetlands vegetation normally has high evaporation rates as compared to other land covers. This intern affects the annual stream flow, which is likely to be less compared 5 to other land uses (Calder, 1992).

The earth's climate is changing gradually. In East Africa for example, catchments are displaying a small increase in precipitation received and this makes them wetter. These changes definitely affect the quantity of stream flow.

\subsection{Application of GIS in hydrological modeling}

10 Geographical Information System (GIS) is an organized collection of computer hardware and software, with supporting personnel, that captures, stores, analyses and display all forms of geo-referenced information (Sabin, 1996).

The primary role of GIS in hydrological modeling is to integrate the ever increasing volumes of diverse spatial and non spatial data. This can be the model input or output.

15 Recent advance in GIS (hardware and software) technology offer unprecedented capabilities for storing and manipulating large quantities of detailed, spatially-distributed watershed data (ASCE, 1999).

SWAT, which is an interface of Arc View GIS, uses Arc View to prepare input data and display the model output as spatial maps, charts or time series data. This makes it easy to study and display the information for assimilation by SWAT.

SWAT is a continuous time model that operates on a daily/sub-daily time step. It is physically based and can operate on large basins for long periods of time (Arnold et al., 1998). The basic model inputs are rainfall, maximum and minimum temperature, radiation, wind speed, relative humidity, land cover, soil and elevation (DEM). The wa-

tershed is subdivided into sub-basins that are spatially related to one another. The sub-basin watershed components can be categorized into the following components - hydrology, weather, erosion and sedimentation, soil temperature, plant growth, nutrients, pesticides and land management. In the land phase of the hydrologic cycle,
HESSD

8, 1765-1797, 2011

\section{Hydrologic analysis for river Nyando using SWAT}

A. O. Opere and B. N. Okello

Title Page

Abstract Introduction

Conclusions

Tables

References

Figures

14

$\rightarrow$

4

Back

Close

Full Screen / Esc

Printer-friendly Version

Interactive Discussion 
runoff is predicted separately for each hydrologic response unit (HRU) and routed to obtain the total runoff for the watershed. Once the loadings (water, sediment, nutrients and pesticides) to the main channel are determined, they are routed through the stream network of the watershed.

5 The water balance equation used in SWAT for the land phase of the hydrologic cycle is given by Neitsch et al. (2002a) as:

$S W_{t}=S W_{0}+\sum_{i=1}^{t}(R-Q-E-W-G)$

Where: $S W_{t}$ is the final water content on day $i(\mathrm{~mm})$,

$S W_{0}$ is initial water content on day $i(\mathrm{~mm})$,

$T$ is the time (days),

$R$ is the amount of precipitation on day $i(\mathrm{~mm})$,

$Q$ is the amount of surface runoff on day $i(\mathrm{~mm})$,

$E$ is the amount of Evapotranspiration on day $i(\mathrm{~mm})$,

$W$ is the amount of water entering the vadose zone from the soil profiles on day $i(\mathrm{~mm})$,

$G$ is the amount of return flow on day $i(\mathrm{~mm})$.

The hydrologic processes simulated by the sub basins as shown by the water balance equation are precipitation, surface runoff, evapotranspiration, percolation and return 10 flow.

The daily weather data required by SWAT are precipitation, temperature (maximum and minimum), solar radiation, relative humidity and wind speed.

After putting precipitation and temperature (maximum and minimum) data, the weather generator then generates solar radiation and relative humidity for the day.

Runoff is simulated separately for each of the HRU generated and combined to give the total stream flow for the sub-basin which again combines with the other sub-basin's

HESSD

$8,1765-1797,2011$

\section{Hydrologic analysis for river Nyando using SWAT}

A. O. Opere and B. N. Okello

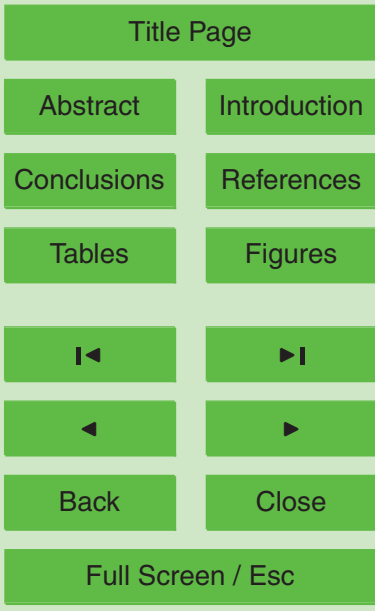

Printer-friendly Version

Interactive Discussion 
to give the stream flow for the whole basin. According to Neitsch et al. (2002) SWAT predicts surface runoff using the modified SCS Curve number method or the Green and Ampt infiltration method. In this study SCS Curve number which is a function of soil permeability, land use and antecedent moisture condition was used.

The basic equation used by the SCS curve number is given by

$Q=\frac{(R-1) 2}{R-1+S}$

Where: $Q$ is the accumulated surface runoff or excess rainfall $(\mathrm{mm})$,

$R$ is the rain depth for the day,

$I$ is the initial abstraction, which include surface storage, interception and infiltration prior to runoff $(\mathrm{mm})$,

$S$ is the retention parameter $(\mathrm{mm})$.

Routing in stream channel is divided in to water, sediment, nutrients and organic chemical routing (Neitsch et al., 2002a). In routing water, SWAT accounts for any losses. These losses include those due to evaporation, transmission or any diversion. The amount of water added as a result of precipitation in the main channel and point sources discharges are also accounted for.

In the channel, manning equation is used to calculate rate and velocity of flow in the reach of each sub basin for a given time step. The manning equation is given by the Eqs. (3) and (4) below for the rate and velocity, respectively.

${ }_{15} q=\frac{A R^{2 / 3} S^{1 / 2}}{n}$

$V=\frac{A R^{2 / 3} S^{1 / 2}}{n}$

Where: $q$ is the rate of flow in the main channel $\left(\mathrm{m}^{3} / \mathrm{s}\right)$;

$A$ is the cross sectional area of the channel $\left(\mathrm{m}^{2}\right)$;
HESSD

$8,1765-1797,2011$

\section{Hydrologic analysis for river Nyando using SWAT}

A. O. Opere and B. N. Okello

Title Page

Abstract Introduction

Conclusions References

Tables Figures

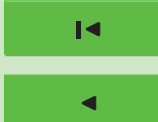

Back

Close

Full Screen / Esc

Printer-friendly Version

Interactive Discussion 
$R$ is the hydraulic radius for a given depth of flow $(\mathrm{m})$;

$S$ is the slope along the channel length $(\mathrm{m} / \mathrm{m})$;

$n$ is the manning coefficient for the channel; and

$V$ is the velocity of the flow $(\mathrm{m} / \mathrm{s})$.

The model assumes that the main channel has trapezoidal shape with a 2:1 run to rise ration. When the volume of water in the reach exceeds the maximum amount that can be contained by the main channel, the excess amount spreads across the flood plain. SWAT routes the stream flow downstream using either variable storage or Muskingum

\section{SWAT input data and their sources}

\section{Digital Elevation Model (DEM)}

A Digital Elevation Model (DEM), gives the elevation, slope and defines the location of the streams network in a basin. A DEM with a spatial resolution of $90 \mathrm{M}$ by $90 \mathrm{M}$ was used in this study and it was obtained from International Centre for Research in Agroforestry (ICRAF).

\section{Land use/cover map}

The land use/cover map gives the spatial extent and classification of various land use/cover classes of the study area. The land use/cover data combined with soil cover data generates the hydrologic characteristics of the basin or the study area, which in turn determines the excess precipitation, recharge to the ground water system and storage in the soil layers.

The land use/cover data was obtained from ICRAF for the two varied years that is for 1987 and 2003.

\section{HESSD}

$8,1765-1797,2011$

\section{Hydrologic analysis for river Nyando using SWAT}

A. O. Opere and B. N. Okello

Title Page

Abstract Introduction

Conclusions References

Tables Figures

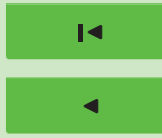

$\rightarrow$

Back

Close

Full Screen / Esc

Printer-friendly Version

Interactive Discussion 


\section{Soil map and data}

The soil data as required by SWAT to predict stream flow should have the hydraulic conductivity properties which include: soil bulk density, saturated hydraulic conductivity and the soil available water capacity (SOL_AWC). The soil data was obtained from

5 the internet (ISREC site), the parameters of the soil such as soil bulk density ( $\mathrm{g} / \mathrm{cc}$ ), saturated hydraulic conductivity, $K_{\mathrm{s}}(\mathrm{mm} / \mathrm{hr})$ and soil available water capacity which were missing were estimated using a hydrology programme called soil water characteristics which was also downloaded from the internet.

\section{Stream flow data}

10 Stream flow data was available for two Stations 1 GD03 and 1GD07. The stations had data ranging from 1950 to 1997, though they had missing gaps. Table 1 gives the summary of the stream flow data and the percentage of missing data for each station used for the study.

\section{Weather data}

15 Rainfall data were available for twelve rainfall recording stations in and around the basin. The collected data ranges between 1960 and 2000 though there were quite a number of missing data. The other weather data used were temperature data (maximum and minimum) for Kericho and Kisumu Meteorological stations.

\section{SWAT model set up}

20 This procedure involved integrating DEM, land use/cover map, soil map and data and weather data to create sub-basins and hydrologic response units (HRUs). This was followed by creating watersheds. The soil and land use data were characterized in the SWAT database. When defining the Hydrologic response unit (HRU), SWAT uses two options that is; the dominant land use/land cover in the sub-basins and soil or

\section{HESSD}

$8,1765-1797,2011$

\section{Hydrologic analysis for river Nyando using SWAT}

A. O. Opere and B. N. Okello

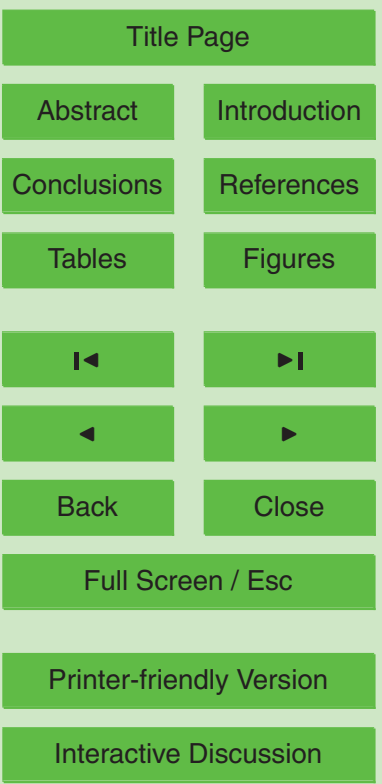


Multiple HRU within the sub-basin (Di Luzio et al., 2002). In this study the dominant land use/land cover and soil was used to define the HRU. This means that the number of HRUs were the same as the number of sub-basins.

\section{Parameter sensitivity analysis}

5 After the model set up (simulation) using the rainfall data to compare the results of the model output vs. the actual measurements, sensitivity analysis was carried out which is an important process in guiding the subsequent calibration process. The sensitivity analysis identified the effects of changing calibration parameters as given by Neitsch et al. (2002b) on stream flow.

10 The initial parameter values (model defaults) were varied one after the other by changing within their suggested range of application as show in the table below. The results of the percentage changes in stream flow were then plotted against each parameter input to test the sensitivity of the parameters.

\section{Soil available water capacity (SOL_AWC)}

15 This is defined as the ability of the soil to hold water and depends on the soil characteristics, hence varied within the soil profile and also in the basin. During the study SOL_AWC was varied within the range of $0.05 \mathrm{~mm}$ of water $/ \mathrm{mm}$ of soil. The result showed that SOL_AWC affects the stream flow as shown in Fig. 1.

SOL_AWC affects both the surface flow and base flow.An increase in SOL_AWC

hold more water.

\section{Initial curve number (CN2)}

$\mathrm{CN} 2$ is a function of soil permeability, land use/ cover and the antecedent soil moisture, it therefore affect the rate of surface runoff generation.

\section{HESSD}

$8,1765-1797,2011$

\section{Hydrologic analysis for river Nyando using SWAT}

A. O. Opere and B. N. Okello

\section{Title Page}

Abstract Introduction

Conclusions

Tables

References

Figures

14

4

Back

Close

Full Screen / Esc

Printer-friendly Version

Interactive Discussion $\rightarrow$ I

$>$

政

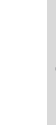


From the graph it shows that an increase in CN2 increases the stream flow, but the effect is more pronounced on the effects on surface run off. The slightly increase in total stream flow could be as a result of ration of surface run off to base flow. The amount of stream flow contributed by the base flow was more than $50 \%$ of the total 5 stream flow as show by base flow separation.

\section{Soil evaporation compensation factor (ESCO)}

ESCO is a coefficient used to modify the depth distribution used to meet soil evaporative demands (Neitsch et al., 2002b).

The default value of ESCO as used during this work was 0.95 , this parameter was varied between $0.1-0.95$. The result obtained from performing the variation of ESCO value showed that a decrease in ESCO value results in decrease in stream flow as well. This can be explained that the amount of water that is availed for evapotranspiration is more. ESCO affects both base flow and surface flow at the same rate.

\section{Threshold depth of water in the shallow aquifer required for the return flow to occur (GWQMN)} 15

The ground water flow to the main channel is allowed only when the depth of water in the shallow aquifer is equal to or greater than the threshold depth of water in the shallow aquifer required for the return flow to occur (GWQMN).

In this study the GWQMN was varied in the range of between $0 \%$ and $50 \%$. The value of GWQMN was put at $0 \mathrm{~mm}$ initially; by increasing the value of GWQMN the result gave a decreasing trend in the simulated baseflow and consequently on the streamflow. The effects of GWQMN on the surfaceflow are not significant.

\section{HESSD}

$8,1765-1797,2011$

\section{Hydrologic analysis for river Nyando using SWAT}

A. O. Opere and B. N. Okello

Title Page

Abstract Introduction

Conclusions

Tables

References

Figures

14

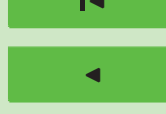

- I

Back

Close

Full Screen / Esc

Printer-friendly Version

Interactive Discussion 


\section{Groundwater "revap” coefficient (GW_REVAP)}

The groundwater "revap" coefficient (GW_REVAP) has the effects on the amount of water that recharges the capillary fringe after evaporation during the dry periods. The capillary fringe is recharged by shallow aquifer during the dry periods.

$5 \quad$ By putting the initial value of the GW_REVAP at $0 \mathrm{~mm}$, then varying it by between $0 \%$ to $50 \%$, the result showed that when the groundwater "Revap" coefficient increases there is a slight decrease in the amount of simulated baseflow and total stream flow. The effects of GW_REVAP on the baseflow were not significant as it was observed to be less than $2 \%$. Change in GW_REVAP is critical as it affects the movement of water 10 from shallow aquifer to the root zone.

\section{Model calibration and validation}

Calibration involve testing model with known input and output data in order to adjust some parameters, while validation involves comparison of the model results with an independent datasets from the used during calibration without any further adjustment 15 of the calibration parameters.

\section{Calibration}

Calibration procedures were performed while following the advice provided in some publications by the principal SWAT model developer, Dr. Jeff Anorld, and his colleagues at the USDA ARS-Blackland (Texas) Research Centre (Arnold et al., 2000; Santhi et al., 2002; Neitsch et al., 2002b).

In this study, the model calibration was done against both surface flow and base flow. The input data (stream flow and weather) used for calibration was for the period of 1970 and 1973 (based on daily values). The gauging station 1GD03 which is located within the main Nyando River was used for calibration.

\section{HESSD}

$8,1765-1797,2011$

\section{Hydrologic analysis for river Nyando using SWAT \\ A. O. Opere and B. N. Okello}

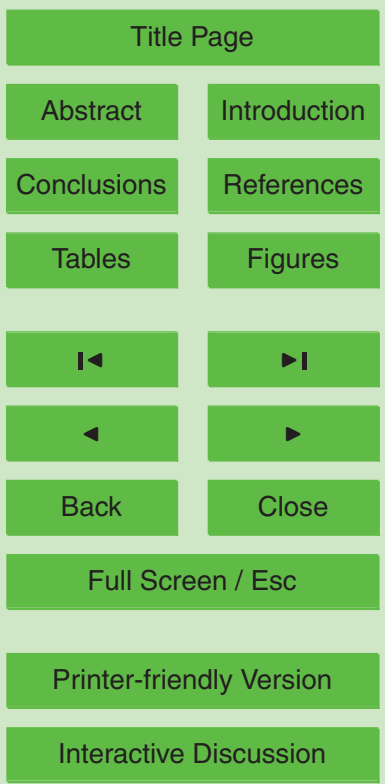


The goodness of fit between observed and simulated stream flow was assessed for the aforementioned (1GD03) station, the $R^{2}$ was found to be 0.24 while the NSE was 0.46 , respectively. The low value of $R^{2}$ and NSE could be attributed to lots of data gaps in the station and also the effects of combined tributaries. The station is located about $510 \mathrm{~km}$ upstream of Ahero Bridge just before the flood plain. The model over estimated the low flows at this station while the high flows were well estimated.

\section{Base flow separation}

The stream flow data was split into two base flow and surface flow. Table 7 gives a summary of the base flow separation results. The daily stream flow data used to perform the separation was for the gauging station 1GD03 for the period of 1974 .

The alpha factor gives the base flow recession constant factor; it is an important parameter in the base flow estimation. Base flow day are the number of days for the base flow recession to decline in log cycle.

Based on the average pass 1 and 2 from Table 7, the fraction of stream flow contributed by base flow constituted between 0.49 and 0.73 , the value is dependent on the location of the gauging station and the number of tributaries joining at the gauging station.

\section{Validation}

To ascertain that calibrated model could be used in Nyando basin, a model validity test was carried out. This was achieved by using a different data sets from the ones used during calibration of the model (1976-1978).

The calibration and validation of the SWAT model for Nyando basin showed that the model could be used to simulate the stream flow in the basin as it gave good results. The fair performance of the model in terms of the values obtained for $R^{2}$ can be improved later on by applying good quality datasets and representative historic data used.

\section{HESSD}

$8,1765-1797,2011$

\section{Hydrologic analysis for river Nyando using SWAT}

A. O. Opere and B. N. Okello

Title Page

Abstract Introduction

Conclusions

Tables

References

Figures

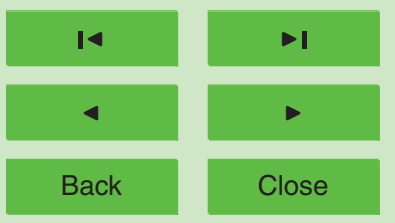

Full Screen / Esc

Printer-friendly Version

Interactive Discussion 


\section{Impact of land use/cover on stream flow}

A comparison on the land use/cover maps for the two years 1980's and 2003 showed that there has been a notable changes in land use/cover in the basin over the years. Accord to the land use/cover map there has been a slight decrease in forest cover by

$5 \quad 7.6 \%$ while the area under swamp has seen quite a decline of about $34 \%$. Agriculture (Mixed agriculture, Sugarcane, Tea, and agriculture dense) which has seen slight improvement by gaining about $2.3 \%$ more of the total land it was occupying in the year 1980's. Within the agricultural sector, Sugar cane plantation has expanded a lot by about $157 \%$ while the area under mixed forest has experience the decline in areal coverage of about $18 \%$. The changes in land use/cover can be attributed to high population pressure which has made agricultural activities increase by encroaching into areas which were once vulnerable (steep slope, flood plains) and uncultivated lands.

The forest cover has remained almost intact with small encroachment in the South of Mau and West of Nandi for new settlements. The study therefore shows that the land use/ cover change is dynamic and therefore the rate of deforestation should be checked properly otherwise continued deforestation would lead into complete depletion of the forest hence alteration into the stream flow.

The land use/cover (map) data for the two cases were loaded in the SWAT interface small tenuously. After each loading the interface including the land use/cover report, this gives the percentage and areal coverage of each land use/cover. The changes in land use as quantified from the two maps were used to develop the land use scenarios for this research work. The base scenario is taken as the simulation values from the model without any modification of the data used.

The land use/cover map was then loaded in the SWAT interface using the varied scenarios while keeping the other parameters constant, then stream flow was simulated for each scenario to establish the impact of land use/cover change on the stream flow.

The results from the land use/cover changes scenario showed that different land use/cover categories have different stream flow characteristics. The peak, mean and
HESSD

8, 1765-1797, 2011

\section{Hydrologic analysis for river Nyando using SWAT}

A. O. Opere and B. N. Okello

Title Page

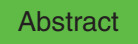

Introduction

Conclusions

Tables

References

Figures

14

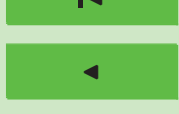

$\rightarrow$

Back

Close

Full Screen / Esc

Printer-friendly Version

Interactive Discussion 
frequency characteristics of the simulated stream flow vary depending on the land use/cover type and scenario. In this study mean stream flow ranged between $19.48 \mathrm{~m}^{3}$ to $32.14 \mathrm{~m}^{3}$. For scenario A: Scenario with low forest cover $(0 \%)$ gave the highest mean stream flow $\left(32.14 \mathrm{~m}^{3}\right)$ while the scenario with $50 \%$ forest cover gave the lowest 5 mean stream flow $\left(19.48 \mathrm{~m}^{3}\right)$. Whereas $100 \%$ forest cover gave a mean stream flow of $26.33 \mathrm{~m}^{3}$. The result can be explained in terms of the effects of forest in arresting the run off. Forests have the effect of reducing runoff, thus the smaller the area under the forest the more the runoff hence the high increase in the stream flow.

Scenario B: Where agricultural dense was the dominant land use/cover, the stream 10 flow registered the highest value both mean and peak $\left(32.14 \mathrm{~m}^{3}\right.$ and $\left.121.13 \mathrm{~m}^{3}\right)$, respectively, this can be said to be as a result of crops which demand less soil moisture than forests thus rainfall satisfies the soil moisture deficit in agricultural lands more quickly than in forests thereby generating more runoff hence increased stream flow.

\section{Conclusion and recommendation}

\section{Conclusion}

SWAT model can simulate stream flow in Nyando Basin. The performance of the model varied depending on the available input data. The coefficient of determination $\mathrm{R} 2$ varies for observed and simulated stream flow at river gauging station.

The relationship between land use/ cover change and stream flow is very significant in Nyando Basin. The observation made is that with decreased Forest Cover up to $0 \%$ there is increased stream flow mean and peak and increased forests cover i.e. $100 \%$ results in decreased mean and peak stream flow. It therefore worth noting that conversion of forest and swamp areas to agricultural land can be attributed the increased annual flooding in the basin hence the need to control forest exercising.

\section{HESSD}

$8,1765-1797,2011$

\section{Hydrologic analysis for river Nyando using SWAT}

A. O. Opere and B. N. Okello

Title Page

Abstract Introduction

Conclusions

Tables

References

Figures

14

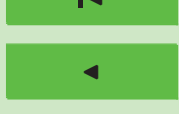

- I

Back

Close

Full Screen / Esc

Printer-friendly Version

Interactive Discussion 


\section{Recommendations}

The potentials of SWAT in channel routing such as sediment transport, agricultural chemical and crop yields should be explored as a way of making SWAT be a tool for watershed management to be used by the managers for decision making.

5 tion in deforestation encouraged so as to control the frequent flooding in the basin.

Acknowledgements. The authors would like to thank the Flemish Government for the financial support, which enabled the successful implementation of the research from which this paper is produced. We are also grateful to UNESCO CAIRO Office and the Department of Water Resources Engineering, University of Dar Es Salaam, for efficient coordination of the FRIEND/Nile project and the HM component respectively.

\section{References}

ASCE: GIS Modules and Distributed Models of the Watershed, A report from ASCE Task Committee, 1999, American Society of Civil Engineers, USA, August, 1999.

Calder, I. R. and Maidment, D. R.: Hydrologic effects of land-use change, Handbook of Hydrology, McGraw-Hill Inc, New York, USA, 13.1-13.50, 1992.

Calder, I. R.: Water Resources and Land useissues, SWIM Paper 3, International Water Management Institute, Colombo, Sirilanka, 1998.

Di Luzio, M., Srinivasan, R., Arnold, J. G., and Neitsch, S. L.: ArcView Interface for SWAT2000 User's Guide, TWRI Report TR-193, Texas Water Resources Institute, College Station, TX, 2002.

McCulloch, J. S. G. and Robinson, M.: History of Forest Hydrology, J. Hydrol., 150, 189-216, 1993.

Neitsch, S. L., Arnold, J. G., Kiniry, J. R., Williams, J. R., and King, K. W.: Soil and Water Assessment Tool, Theoretical Documentation Version 2000, Black land Research and Extension centre, Texas Agriculture Experiment Station Texas, Texas Water resources Institute publishers, TWRI Report TR-191, College station, Texas, USA, 2002a.

\section{HESSD}

8, 1765-1797, 2011

\section{Hydrologic analysis for river Nyando using SWAT}

A. O. Opere and B. N. Okello

Title Page

Abstract

Introduction

Conclusions

Tables

Figures

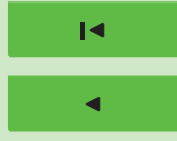

- I

Back

Close

Full Screen / Esc

Printer-friendly Version

Interactive Discussion 
Neitsch, S. L., Arnold, J. G., Kiniry, J. R., Williams, J. R., and King, K. W.: Soil and Water Assessment Tool, Theoretical Documentation Version 2000, Black land Research and Extension centre, Texas Agriculture Experiment Station Texas, 2002b.

Sabin, F. F.: Remote Sensing Principals and Interpretation, Third edition, Freeman and Company New York, USA, 494 pp., 1996.

\section{HESSD}

$8,1765-1797,2011$

\section{Hydrologic analysis for river Nyando using SWAT}

A. O. Opere and B. N. Okello

Title Page

Abstract Introduction

Conclusions References

Tables Figures

14

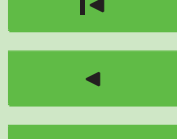

Back

Close

Full Screen / Esc

Printer-friendly Version

Interactive Discussion 


\section{HESSD}

$8,1765-1797,2011$

\section{Hydrologic analysis for river Nyando using SWAT \\ A. O. Opere and B. N. Okello}

Table 1. Summary of available streamflow data for Nyando Basin.

\begin{tabular}{lcccc}
\hline $\begin{array}{l}\text { Gauging } \\
\text { station }\end{array}$ & River & $\begin{array}{c}\text { Daily Mean } \\
\text { flow (M3/s) }\end{array}$ & $\begin{array}{c}\text { Period } \\
\text { recorded }\end{array}$ & $\begin{array}{c}\text { Percentage } \\
\text { missing }\end{array}$ \\
\hline 1GD03 & Sondu & 17.14 & $1956-1997$ & 7 \\
1GD07 & Sondu & 12.54 & $1963-1963$ & 25 \\
\hline
\end{tabular}

Source: MWI.

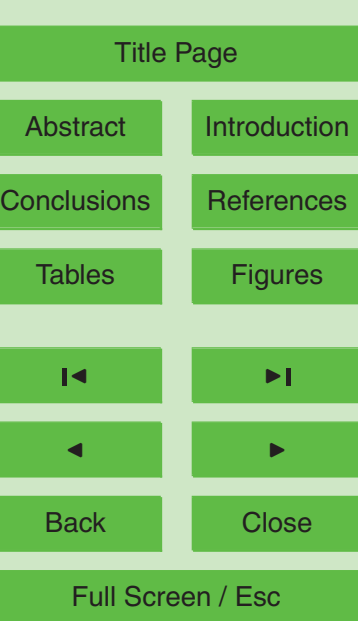

Printer-friendly Version

Interactive Discussion 


\section{HESSD}

$8,1765-1797,2011$

\section{Hydrologic analysis for river Nyando using SWAT}

\begin{tabular}{llcr}
\hline $\begin{array}{l}\text { Rainfall } \\
\text { station ID }\end{array}$ & Name & $\begin{array}{c}\text { Period } \\
\text { recorded }\end{array}$ & $\begin{array}{r}\text { Percentage } \\
\text { missing }\end{array}$ \\
\hline 9035020 & Lumbwa Soil Cionservation Service & $1960-2000$ & 11 \\
9035148 & Koru mission & $1962-2000$ & 6 \\
8935148 & Kipkurere forest station & $1960-2000$ & 7 \\
9034086 & Ahero, Kano Irrigation Scheme & $1962-2000$ & 4 \\
8935001 & Songhor, Kaabirir & $1960-1993$ & 9 \\
9035075 & Kericho Kaisugu house & $1960-2000$ & 5 \\
8935159 & Ainabkoi, Corengoni forest station & $1964-1998$ & 4 \\
9035279 & Kericho Meteorological Station & $1977-1993$ & 34 \\
9034009 & Miwani, European quarters & $1960-1998$ & 7 \\
9034025 & Kisumu Meteorological Station & $1960-1998$ & 34 \\
8935033 & Nandi hills, Savani estate & $1960-1998$ & 17 \\
8935161 & Nandi hills, Kibwari tea estate & $1964-2000$ & 4 \\
\hline
\end{tabular}

Source: KMD.

Table 2. Summary of available rainfall data for Nyando catchment.
A. O. Opere and
B. N. Okello

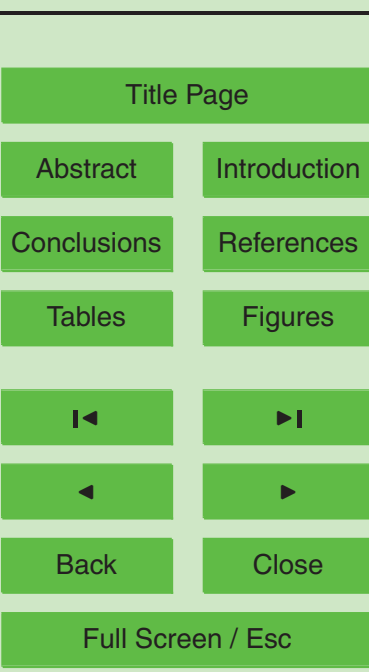

Printer-friendly Version

Interactive Discussion 


\section{HESSD}

8, 1765-1797, 2011

\section{Hydrologic analysis for river Nyando using SWAT}

A. O. Opere and B. N. Okello

Table 3. Summary of available weather data for Nyando catchment.

\begin{tabular}{llcr}
\hline $\begin{array}{l}\text { Meteorological } \\
\text { station }\end{array}$ & Weather parameter & $\begin{array}{c}\text { Period } \\
\text { recorded }\end{array}$ & $\begin{array}{r}\text { Percentage } \\
\text { missing }\end{array}$ \\
\hline Kericho & Maximum Temperature & $1977-2000$ & 39 \\
& Minimum Temperature & $1977-2000$ & 38 \\
Kisumu & Maximum Temperature & $1977-2000$ & 5 \\
& Minimum Temperature & $1977-2000$ & 5 \\
\hline
\end{tabular}

Title Page

Abstract

Introduction

Conclusions

References

Tables

Figures

Source: KMD.

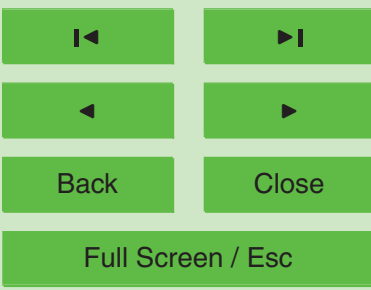

Printer-friendly Version

Interactive Discussion 


\section{HESSD}

$8,1765-1797,2011$

Table 4. Summary of available weather data for Nyando catchment.

\begin{tabular}{llll}
\hline Parameter & $\begin{array}{l}\text { Default } \\
\text { value }\end{array}$ & Range of variation \\
\hline 1. & $\begin{array}{l}\text { Available water capacity of the soil layer } \\
\text { (SOLAWC) }\end{array}$ & Var* & $\pm 0.05 \mathrm{~mm}$ water $/ \mathrm{mm}$ of soil \\
\hline 2. & Soil evaporation compensation factor (ESCO) & 0.95 & $0-1$ \\
\hline 3. & $\begin{array}{l}\text { Threshold depth of water in the shallow } \\
\text { aquifer required for return flow to occur } \\
\text { (GWQMN) }\end{array}$ & 0 & $0-5000 \mathrm{~mm}$ \\
\hline 4. & $\begin{array}{l}\text { Threshold depth for water in the shallow aquifer } \\
\text { for "revap" or percolation to the deep aquifer } \\
\text { to occur (REVAPMN) }\end{array}$ & 0 & $0-500 \mathrm{~mm}$ \\
\hline 5. Initial soil curve number for moisture & Var* & \pm 8 \\
& condition II (CN2) & & \\
\hline 6. Ground water "revap" coefficient (GWREVAP) & 0.02 & $0.02-0.2 \mathrm{~mm}$ \\
\hline
\end{tabular}

$\operatorname{Var}^{\star}$ the default parameter value varied per sub-basin.

\section{Hydrologic analysis for river Nyando using SWAT}

A. O. Opere and B. N. Okello

Title Page

Abstract Introduction

Conclusions

References

Tables

Figures

14

4

Back

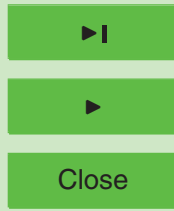

Full Screen / Esc

Printer-friendly Version

Interactive Discussion 
Table 5. Soil and shallow aquifer water balance for each sub basin used by SWAT.

HESSD

\begin{tabular}{|c|c|c|c|c|c|c|}
\hline $\begin{array}{l}\text { Sub } \\
\text { basin }\end{array}$ & $\begin{array}{l}\text { GWQMN } \\
(\mathrm{mm})\end{array}$ & $\begin{array}{l}\text { GW_REVAP } \\
(\mathrm{mm})\end{array}$ & $\begin{array}{l}\text { REVAPMN } \\
(\mathrm{mm})\end{array}$ & ESCO & $\mathrm{CN} 2$ & $\begin{array}{c}\text { SOL_AWC } \\
(\mathrm{mm} \text { of water } / \mathrm{mm} \text { of soil) }\end{array}$ \\
\hline 1 & 100 & 0.12 & 85 & 0.95 & 36 & 0.15 \\
\hline 2 & 100 & 0.12 & 85 & 0.95 & 59 & 0.14 \\
\hline 3 & 185 & 0.17 & 140 & 0.80 & 90 & 0.13 \\
\hline 4 & 185 & 0.17 & 140 & 0.80 & 86 & 0.13 \\
\hline 5 & 185 & 0.17 & 140 & 0.80 & 78 & 0.14 \\
\hline 6 & 185 & 0.17 & 140 & 0.80 & 80 & 0.13 \\
\hline 7 & 185 & 0.17 & 140 & 0.80 & 78 & 0.12 \\
\hline 8 & 185 & 0.17 & 140 & 0.80 & 78 & 0.10 \\
\hline 9 & 116 & 0.17 & 135 & 0.70 & 71 & 0.13 \\
\hline 10 & 116 & 0.17 & 135 & 0.70 & 71 & 0.13 \\
\hline 11 & 105 & 0.12 & 135 & 0.70 & 68 & 0.16 \\
\hline 12 & 105 & 0.12 & 135 & 0.70 & 75 & 0.13 \\
\hline 13 & 105 & 0.12 & 135 & 0.70 & 75 & 0.15 \\
\hline 14 & 105 & 0.12 & 135 & 0.70 & 42 & 0.14 \\
\hline 15 & 105 & 0.12 & 135 & 0.70 & 75 & 0.14 \\
\hline 16 & 105 & 0.12 & 135 & 0.70 & 75 & 0.14 \\
\hline 17 & 105 & 0.12 & 135 & 0.70 & 85 & 0.16 \\
\hline 18 & 105 & 0.12 & 135 & 0.70 & 75 & 0.13 \\
\hline 19 & 105 & 0.12 & 135 & 0.70 & 75 & 0.14 \\
\hline 20 & 105 & 0.12 & 135 & 0.70 & 85 & 0.16 \\
\hline 21 & 100 & 0.12 & 75 & 0.95 & 87 & 0.13 \\
\hline 22 & 100 & 0.12 & 75 & 0.95 & 87 & 0.14 \\
\hline 23 & 100 & 0.12 & 75 & 0.95 & 83 & 0.11 \\
\hline 24 & 100 & 0.12 & 75 & 0.95 & 84 & 0.14 \\
\hline 25 & 100 & 0.12 & 75 & 0.95 & 84 & 0.14 \\
\hline 26 & 100 & 0.12 & 75 & 0.95 & 87 & 0.13 \\
\hline 27 & 100 & 0.12 & 75 & 0.95 & 84 & 0.13 \\
\hline 28 & 100 & 0.12 & 75 & 0.95 & 77 & 0.16 \\
\hline 29 & 100 & 0.12 & 75 & 0.95 & 84 & 0.14 \\
\hline 30 & 116 & 0.17 & 135 & 0.70 & 71 & 0.13 \\
\hline 31 & 116 & 0.17 & 135 & 0.70 & 77 & 0.11 \\
\hline 32 & 185 & 0.17 & 140 & 0.80 & 78 & 0.10 \\
\hline 33 & 100 & 0.12 & 85 & 0.95 & 59 & 0.13 \\
\hline 34 & 185 & 0.17 & 140 & 0.80 & 78 & 0.13 \\
\hline 35 & 105 & 0.12 & 135 & 0.70 & 75 & 0.14 \\
\hline
\end{tabular}

$8,1765-1797,2011$

\section{Hydrologic analysis for river Nyando using SWAT}
A. O. Opere and
B. N. Okello

Title Page

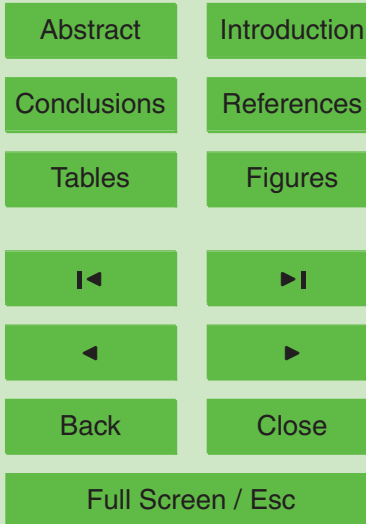

Printer-friendly Version

Interactive Discussion

Note: The value given for SOL_AWC are for the soil first layer. 


\section{HESSD}

$8,1765-1797,2011$

\section{Hydrologic analysis for river Nyando using SWAT \\ A. O. Opere and B. N. Okello}

Table 6. Results obtained after calibrating SWAT using observed stream flow data for the period 1970-1973.

\begin{tabular}{llccc}
\hline & & $\begin{array}{c}\text { Stream flow } \\
\left(\mathrm{m}^{3} / \mathrm{s}\right)\end{array}$ & $\begin{array}{c}\text { Surface flow } \\
\left(\mathrm{m}^{3} / \mathrm{s}\right)\end{array}$ & $\begin{array}{c}\text { Base flow } \\
\left(\mathrm{m}^{3} / \mathrm{s}\right)\end{array}$ \\
\hline 1GD03 & Observed & 20.42 & 5.72 & 14.7 \\
& Simulated & 20.81 & 4.66 & 16.15 \\
& $R^{2}$ & 0.24 & 0.08 & 0.27 \\
& NSE & 0.46 & 0.23 & 0.46 \\
\hline
\end{tabular}

Title Page

Abstract

Conclusions

Tables

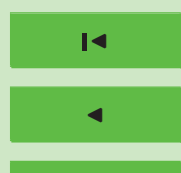

Back

Full Screen / Esc

Printer-friendly Version

Interactive Discussion 


\section{HESSD}

8, 1765-1797, 2011

\section{Hydrologic analysis for river Nyando using SWAT \\ A. O. Opere and B. N. Okello}

Table 7. Summary of Base flow separation results.

\begin{tabular}{cccccc}
\hline $\begin{array}{c}\text { Gauging } \\
\text { station }\end{array}$ & $\begin{array}{c}\text { Base flow } \\
\text { (pass1) }\end{array}$ & $\begin{array}{c}\text { Base flow } \\
\text { (pass2) }\end{array}$ & $\begin{array}{c}\text { Base flow } \\
\text { (pass3) }\end{array}$ & $\begin{array}{c}\text { Alpha } \\
\text { factor }\end{array}$ & $\begin{array}{c}\text { Base flow } \\
\text { days }\end{array}$ \\
\hline 1GD03 & 0.64 & 0.57 & 0.50 & 0.0104 & 96 \\
1GD07 & 0.57 & 0.50 & 0.41 & 0.0160 & 62 \\
\hline
\end{tabular}

Title Page

Abstract

Conclusions

Tables

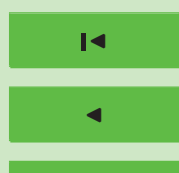

Back

Full Screen / Esc

Printer-friendly Version

Interactive Discussion 


\section{HESSD}

8, 1765-1797, 2011

\section{Hydrologic analysis for river Nyando using SWAT}

Table 8. Quantified land use/cover change in the Nyando Basin.

\begin{tabular}{lrrrrrr}
\hline $\begin{array}{l}\text { Land use/ } \\
\text { cover }\end{array}$ & $\begin{array}{r}1980 \text { 's } \\
\text { Area } \\
\left(\mathrm{km}^{2}\right)\end{array}$ & $\begin{array}{r}2003 \\
\text { Area } \\
\left(\mathrm{km}^{2}\right)\end{array}$ & $\begin{array}{r}\text { Change } \\
\text { Area } \\
\left(\mathrm{km}^{2}\right)\end{array}$ & $\%$ \\
\hline Forest & 503 & 14.5 & 465 & 13.4 & -38 & -7.5 \\
Swamp & 88 & 2.5 & 58 & 1.7 & -30 & -34.0 \\
Agriculture & 2880 & 83 & 2948 & 84.9 & 67 & 2.3 \\
Mixed agriculture & 390 & 11.2 & 320 & 9.2 & -70 & -18.0 \\
Tea & 48 & 1.4 & 52 & 1.5 & 4 & 8.7 \\
Sugarcane & 58 & 1.7 & 148 & 4.3 & 91 & 157.4 \\
Agricultural dense & 2385 & 68.7 & 2428 & 69.9 & 43 & 1.8 \\
Total & 3471 & 100 & 3471 & 100 & 0 & 0.0 \\
\hline
\end{tabular}
A. O. Opere and
B. N. Okello

Title Page

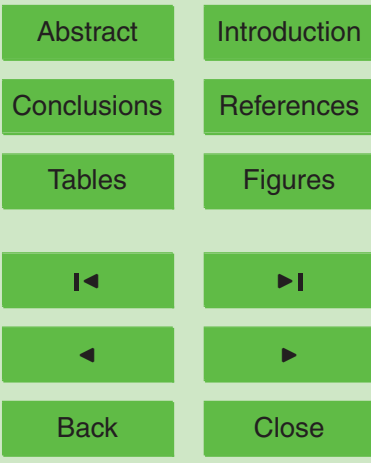

Full Screen / Esc

Printer-friendly Version

Interactive Discussion 


\section{HESSD}

$8,1765-1797,2011$

\section{Hydrologic analysis for river Nyando using SWAT \\ A. O. Opere and B. N. Okello}

Table 9. Land use/cover scenario as used to study the impact of land use/cover on stream flow.

\begin{tabular}{lrcccc}
\hline & $\begin{array}{c}\text { Forest } \\
(\%)\end{array}$ & $\begin{array}{c}\text { Agriculture } \\
\text { dense } \\
(\%)\end{array}$ & $\begin{array}{c}\text { Mixed } \\
\text { agriculture } \\
(\%)\end{array}$ & $\begin{array}{c}\text { Plantation } \\
(\%)\end{array}$ & $\begin{array}{c}\text { Others } \\
(\%)\end{array}$ \\
\hline Base & 14 & 69 & 11 & 3 & 3 \\
2 & 100 & 0 & 0 & 0 & 0 \\
3 & 50 & 30 & 13 & 5 & 2 \\
4 & 0 & 80 & 13 & 5 & 2 \\
\hline
\end{tabular}

Title Page

Abstract

Introduction

Conclusions

References

Tables

Figures

14

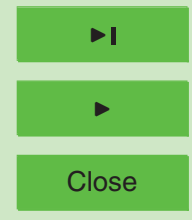

Back

Full Screen / Esc

Printer-friendly Version

Interactive Discussion 


\section{HESSD}

$8,1765-1797,2011$

\section{Hydrologic analysis for river Nyando using SWAT \\ A. O. Opere and B. N. Okello}

Table 10. Mean and peak of simulated stream flow for the land use/cover scenario at gauging station $1 \mathrm{GD} 03$.

\begin{tabular}{lrrr}
\hline Scenario & $\begin{array}{c}\text { Forest } \\
(\%)\end{array}$ & $\begin{array}{r}\text { Mean } \\
\left(\mathrm{m}^{3} / \mathrm{s}\right)\end{array}$ & $\begin{array}{r}\text { Peak } \\
\left(\mathrm{m}^{3} / \mathrm{s}\right)\end{array}$ \\
\hline A & 100 & 26.33 & 69.49 \\
B & 0 & 32.14 & 121.13 \\
C & 50 & 19.48 & 109.36 \\
D (Base) & 14 & 20.42 & 111.97 \\
\hline
\end{tabular}

Title Page

Abstract

Conclusions

Tables

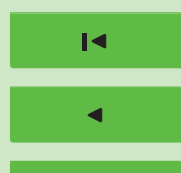

Back

Full

Printer-friendly Version

Interactive Discussion 


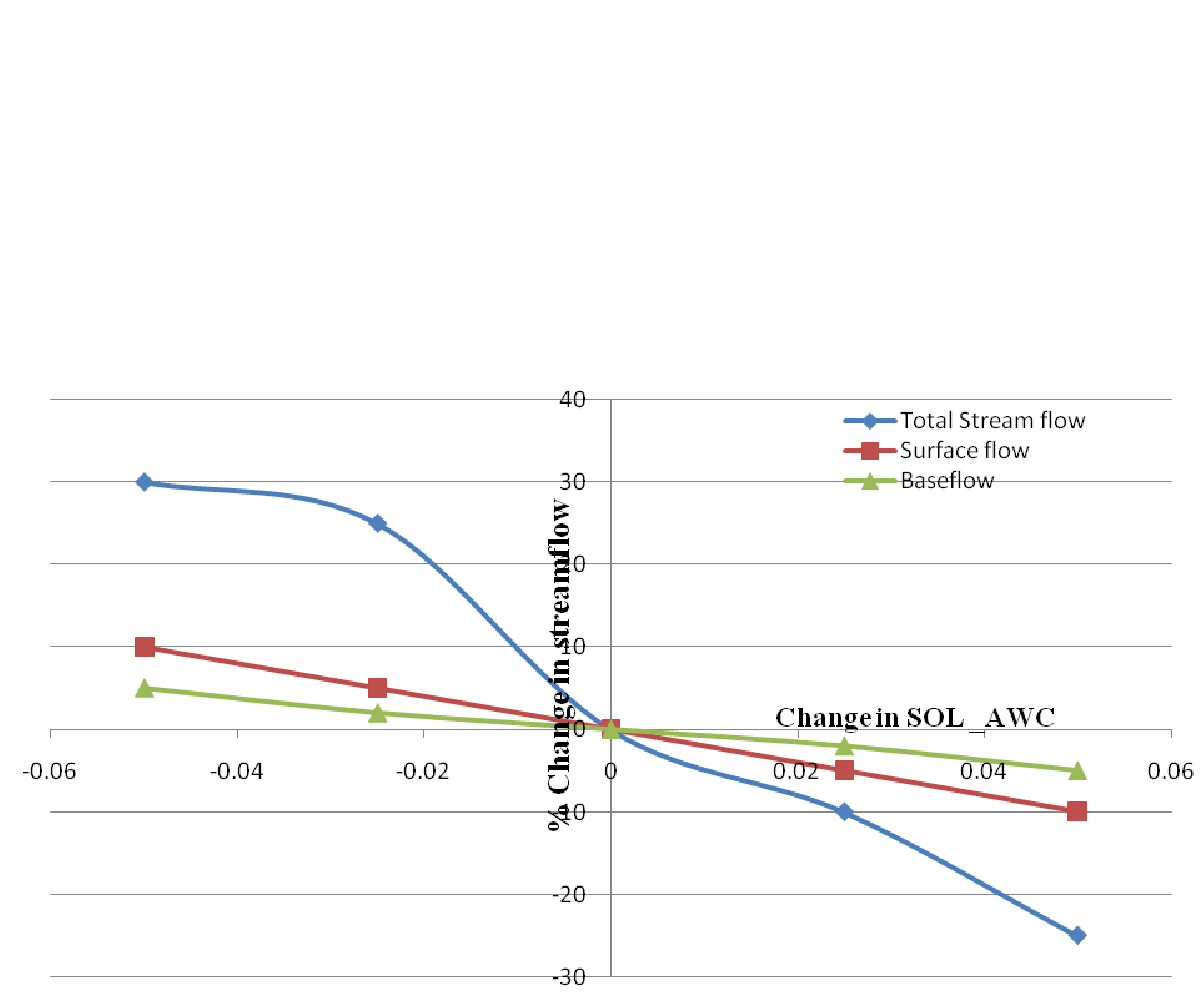

\section{HESSD}

8, 1765-1797, 2011

\section{Hydrologic analysis for river Nyando using SWAT
A. O. Opere and
B. N. Okello

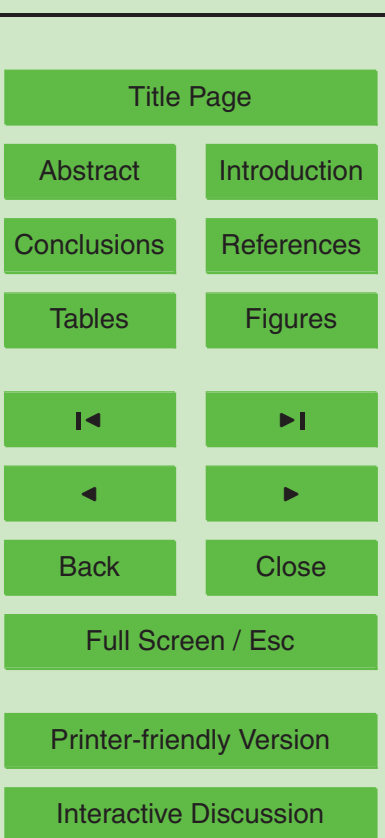




\section{HESSD}

8, 1765-1797, 2011

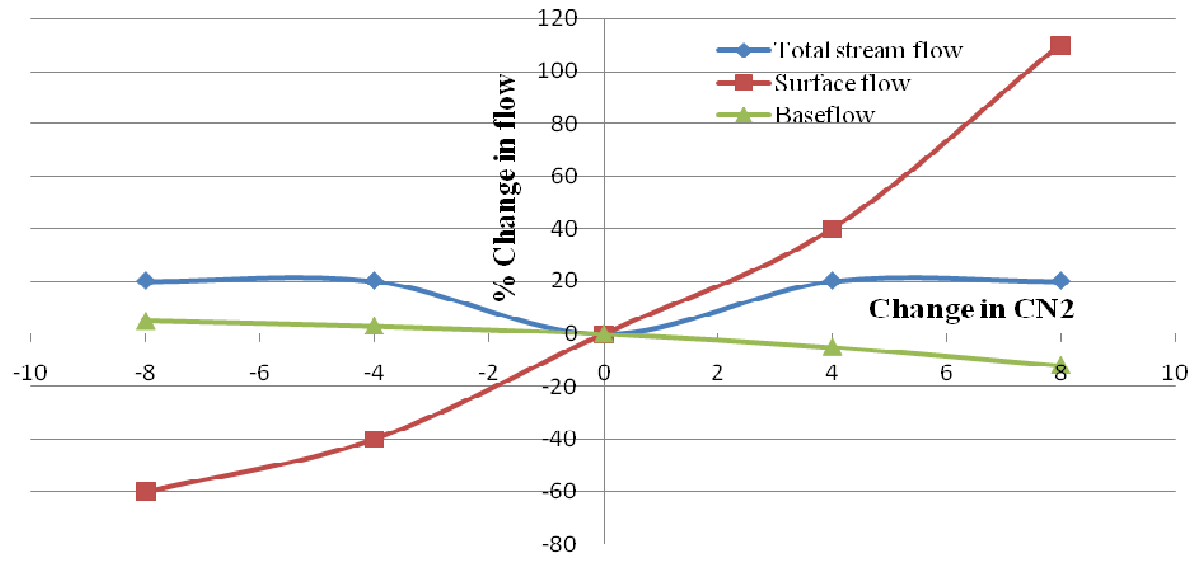

Fig. 2. The effect of changing CN2 on simulated stream flow. 


\section{HESSD}

8, 1765-1797, 2011

\section{Hydrologic analysis for river Nyando using SWAT
A. O. Opere and
B. N. Okello

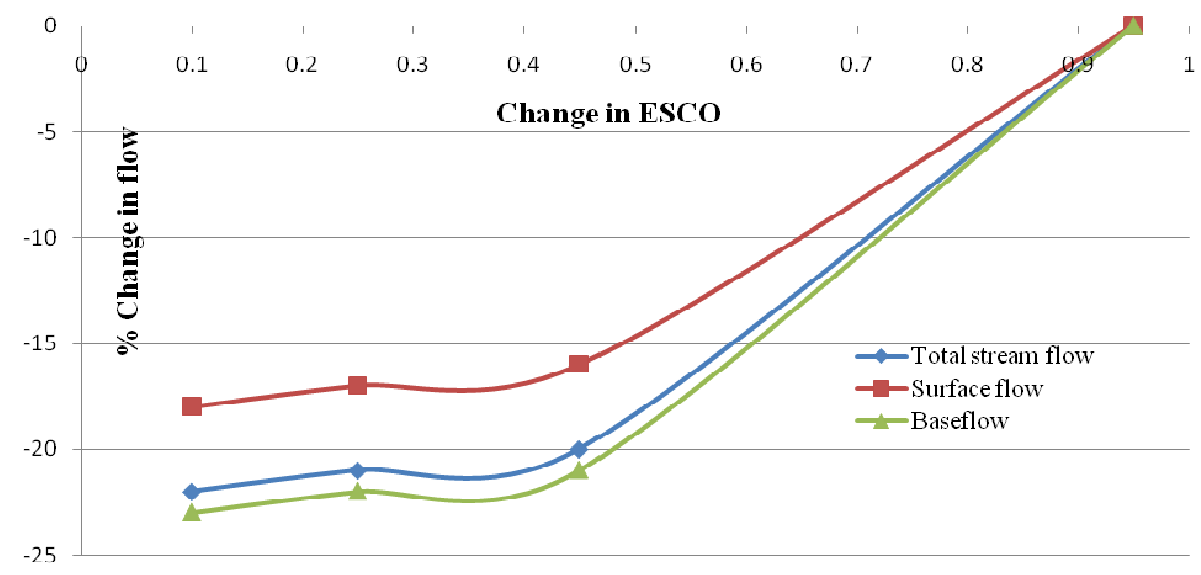

Title Page

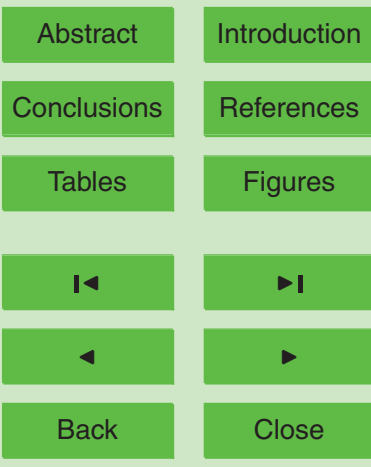

Full Screen / Esc

Printer-friendly Version

Interactive Discussion 


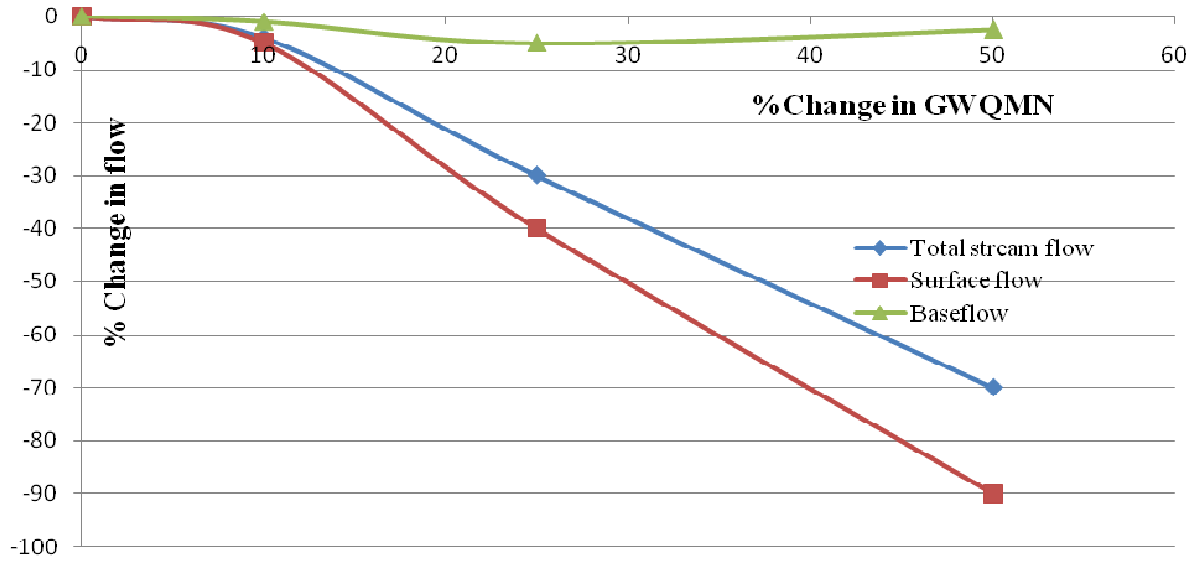

\section{HESSD}

8, 1765-1797, 2011

\section{Hydrologic analysis} for river Nyando using SWAT

A. O. Opere and B. N. Okello

Title Page

Abstract

Introduction

Conclusions

References

Tables

Figures

14

4

Back

Full Screen / Esc

Printer-friendly Version

Interactive Discussion 


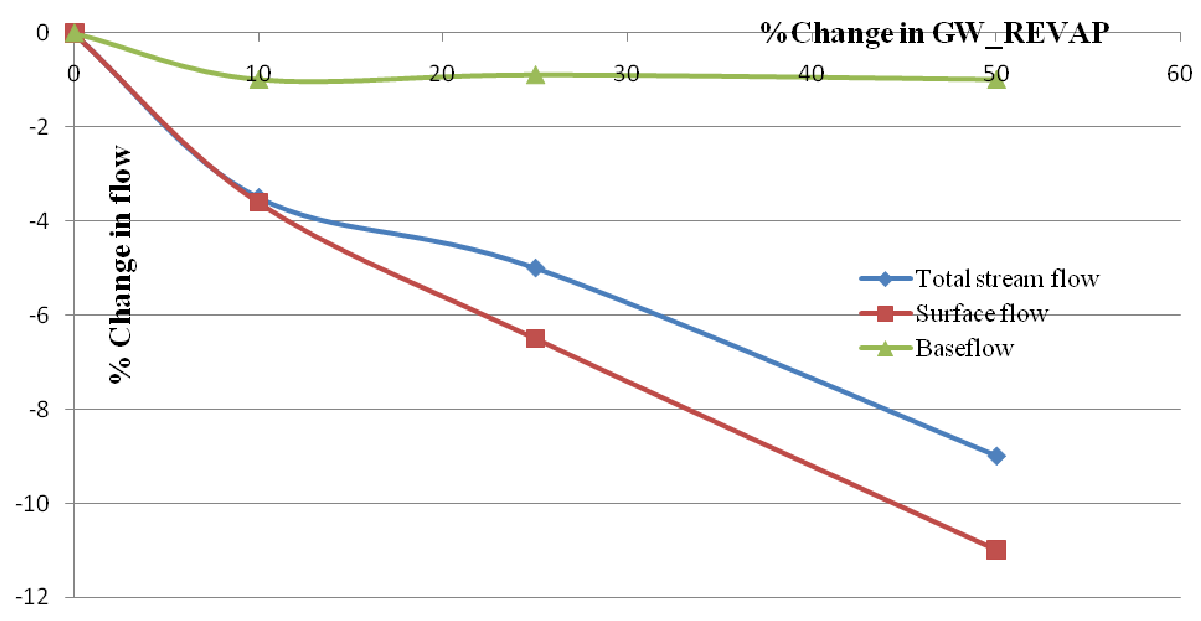

Fig. 5. Effects of changing GW_REVAP on simulated stream flow.

\section{HESSD}

$8,1765-1797,2011$

Hydrologic analysis for river Nyando using SWAT

A. O. Opere and B. N. Okello

Title Page

Abstract

Introduction

Conclusions

References

Tables

Figures

14

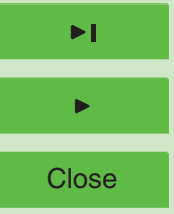

Back

Full Screen / Esc

Printer-friendly Version

Interactive Discussion 


\section{HESSD}

8, 1765-1797, 2011

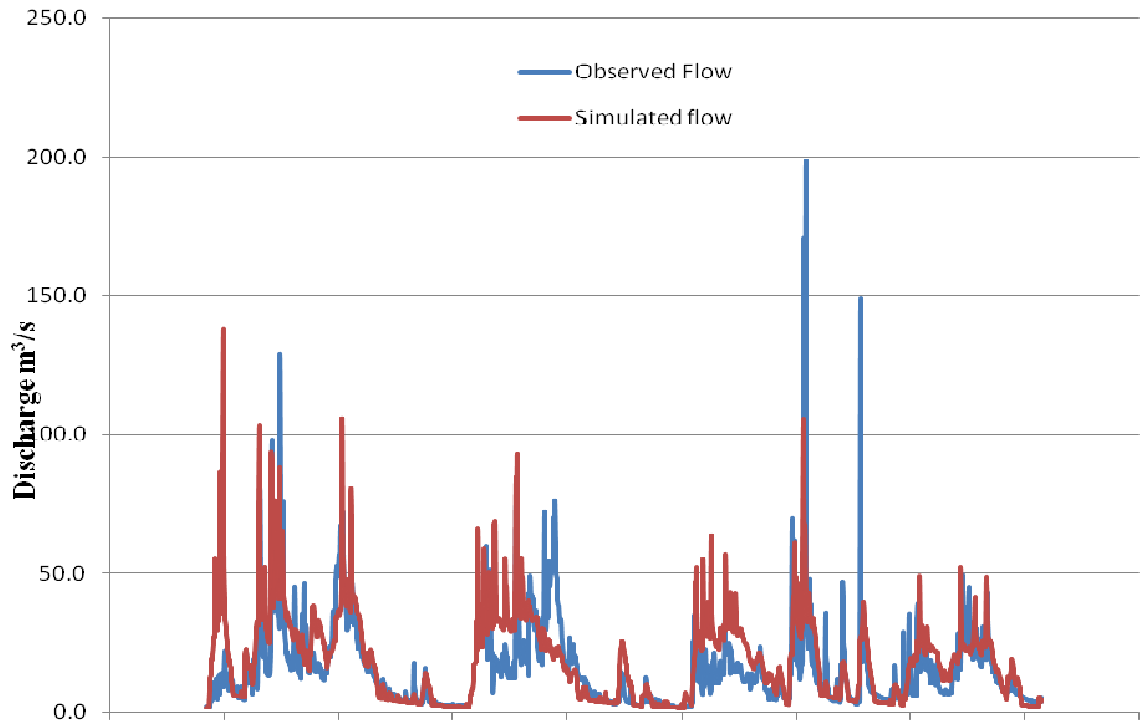

Hydrologic analysis for river Nyando using SWAT

A. O. Opere and B. N. Okello

Title Page

Abstract

Introduction

Conclusions

References

Tables

Figures

14

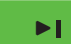

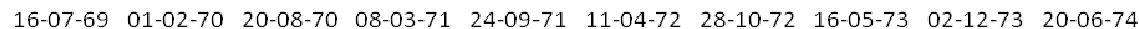
Date

Fig. 6. Calibrated hydrograph for 1GD03 for the period (1970-1973).

\section{Full Screen / Esc}

Printer-friendly Version

Interactive Discussion 